\title{
Cost of Production for Processed Oranges in Southwest Florida in 2020/21
}

\author{
Ariel Singerman ${ }^{2}$
}

This publication presents estimates for the cost of production per acre for processed oranges grown in southwest Florida in $2020 / 21$. The estimates were obtained by surveying growers by mail regarding the actual costs of their production programs, which allows reporting representative estimates of the current grove caretaking practices, input combinations, costs, and production levels in commercial operations. This is important because, since the outbreak of HLB, growers have been changing their practices from season to season in an attempt to cope with the disease. Thus, surveying growers allows not only to report estimates that closely reflect their costs but also to track the changes they make to their cultural practices. The cost estimates below do not represent any individual operation; instead, their purpose is to serve as a benchmark for the Florida citrus industry. Typical users of these estimates include growers, consultants, property appraisers, and researchers.

The number of acres managed by the combined operations of the sample of participating growers accounted for approximately 25,800 acres; representing $11 \%$ of the acreage devoted to oranges in southwest Florida, which was estimated at 242,241 (USDA-NASS, 2021). The questionnaire asked growers to provide annual, per-acre costs by program for a "typical" irrigated, mature grove (10+ years old), including costs related to their tree replacement program. The figures below were obtained by computing the weighted average of the responses by the acreage of each of the growers.

Table 1 shows the cultural cost of production by program. The estimates include both the cost of materials and the cost associated with their application. The total cost for weed management, which includes chemical and mechanical mowing as well as herbicides, was $\$ 215.64$ per acre. At $\$ 479.71$ per acre, foliar sprays represented the largest cost. Fertilizer was the second largest expense at $\$ 387.96$ per acre. The expense for pruning was $\$ 33.58$ per acre, while that for irrigation was $\$ 197.15$ per acre. Adding all the costs listed above, the cultural cost of growing oranges for processing during 2019/20 without tree replacement was $\$ 1,314.04$ per acre.

Growers were also asked to provide details regarding their reset practices, including the number of trees replaced in their groves. On average, growers replaced six trees per acre during 2020/21. The total cost of tree replacement, including tree removal, site preparation, and supplemental care of those six young trees was estimated at $\$ 193.75$ per acre. Adding such a figure to the total cost above adds up to a total production cost with tree replacement of $\$ 1,507.79$ per acre.

Figure 1 depicts a double pie chart. The larger pie shows the cost of each program as well as the percentage relative to the total cultural production costs with tree replacement.

1. This document is FE1111, one of a series of the Food and Resource Economics Department, UF/IFAS Extension. Original publication date February 2022. Visit the EDIS website at https://edis.ifas.ufl.edu for the currently supported version of this publication.

2. Ariel Singerman, associate professor and Extension economist, Food and Resource Economics Department; UF/IFAS Citrus Research and Education Center, Lake Alfred, FL 32850

The Institute of Food and Agricultural Sciences (IFAS) is an Equal Opportunity Institution authorized to provide research, educational information and other services

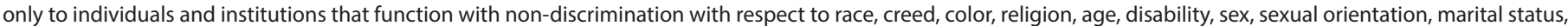

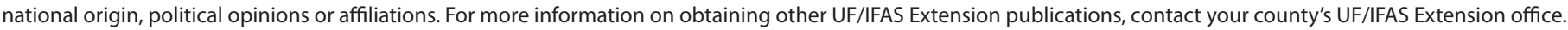
U.S. Department of Agriculture, UF/IFAS Extension Service, University of Florida, IFAS, Florida A \& M University Cooperative Extension Program, and Boards of County Commissioners Cooperating. Andra Johnson, dean for UF/IFAS Extension. 
The smaller pie in Figure 1 provides greater detail regarding the individual components included in foliar sprays. Insecticides accounted for $\$ 161$ per acre (which represented 10\% of the cultural cost of production); fungicides accounted for $\$ 132$ per acre (9\%); foliar nutritionals accounted for $\$ 59$ per acre (4\%); aerial application totaled $\$ 12$ per acre (1\%); and ground application of materials was $\$ 117$ per acre (8\%).

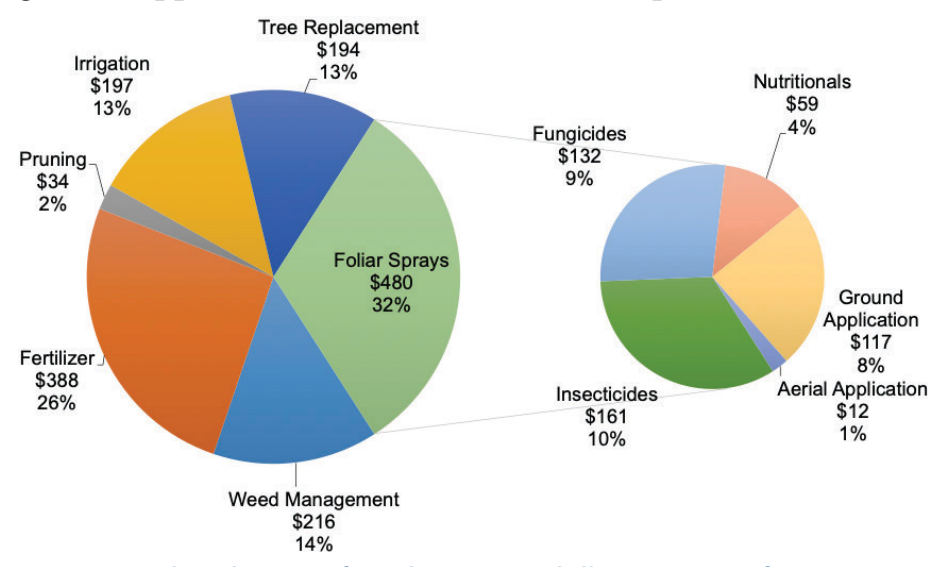

Figure 1. Cultural Costs of Production (in dollars per acre) for Processed Oranges Grown in Southwest Florida, 2020/21.

Figure 2 shows a comparison of the cost of the caretaking programs in 2020/21 relative to $2019 / 20$. The main changes in practices in 2020/21 compared to the previous season are as follows: First, the largest reduction in spending was for tree replacement, which was cut back, on average, by $\$ 99$ per acre. The second-largest reduction was for foliar nutritionals. On average, growers cut back that program by $\$ 57$ per acre, which represents almost a 50\% change relative to last season. The third largest reduction was in pruning, which was reduced by $\$ 20$ per acre compared to last season. The cutbacks were for most programs, and they were the rational response of growers to the significant decrease in prices during the previous season. The only program for which growers, on average, increased their spending significantly was fungicides, which, on average, increased by $\$ 88$ per acre.

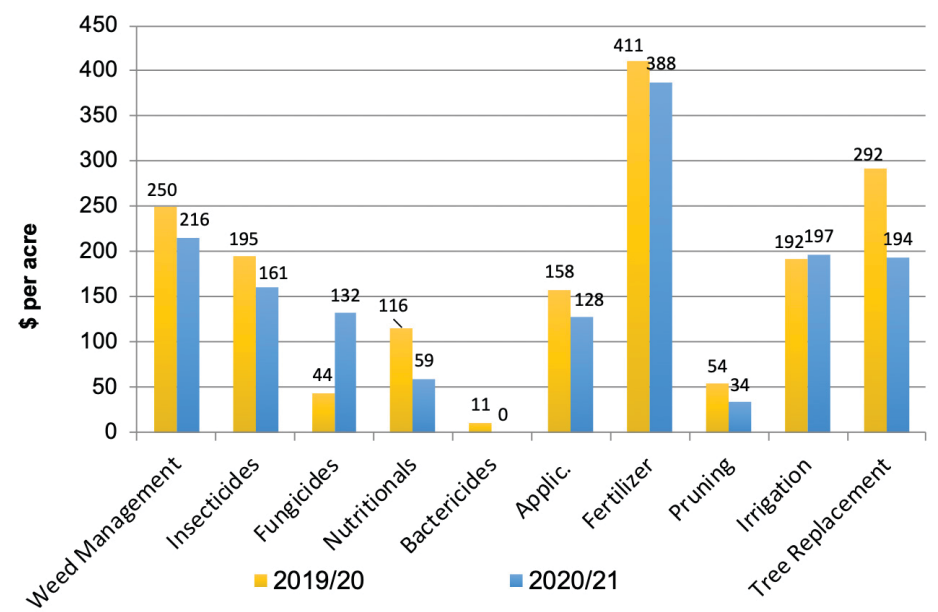

Figure 2. Cost of Production by Program for Processed Oranges Grown in Southwest Florida, 2019/20 vs. 2020/21.
In addition to cultural costs, growers typically have to incur in other costs when managing their groves; these other costs include management, regulatory, and opportunity costs. Table 2 shows the total cost of production for processed oranges grown in southwest Florida during 2020/21 was $\$ 1,882.43$ per acre, down $\$ 213$ per acre compared to the previous season. Based on this estimate, the break-even prices per box and per pound solids for different levels of yield are presented in Table 3. Break-even prices were calculated on an on-tree and delivered-in basis. The latter assumes harvesting costs per box were $\$ 3.22$ for Early- and Mid-season oranges and $\$ 3.33$ for Valencia oranges. The calculations in Table 3 also include the Florida Department of Citrus (FDOC) assessment of $\$ 0.12$ per box for the 2020/21 season. Thus, for example, the on-tree and delivered-in break-even prices for Early- and Mid-season oranges for covering the total costs of production with yield at 150 boxes per acre were $\$ 2.44$ and $\$ 3.09$ per pound solids, respectively. For Valencia oranges, the on-tree and delivered-in break-even prices for covering the total costs of production with yield at 150 boxes per acre were $\$ 2.22$ and $\$ 2.83$ per pound solids, respectively.

\section{Summary}

This publication presents a summary of the 2020/21 costs of production for processed oranges grown in southwest Florida. The methodology chosen to collect the data consisted of surveying growers directly so as to reflect their costs. The main change this season was the decrease in the spending of almost all grove caretaking programs relative to the previous season as a response to the decrease in prices that occurred in the previous season. The total cost of production for processed oranges in 2020/21 was $\$ 1,882$ per acre, down $\$ 213$ per acre compared to $\$ 2,095$ in 2019/20. Typical users of these estimates include growers and consultants, who use them as a benchmark; property appraisers, who use them to compute the taxes for property owners; and researchers, who use the estimates to evaluate the economic feasibility of potential new technologies.

\section{Reference}

USDA-NASS. 2021. Florida Citrus Statistics 2019/20. 
Table 1. Cultural Costs of Production per Acre for Processed Oranges Grown in Southwest Florida, 2020/21.

\begin{tabular}{|c|c|c|c|c|c|}
\hline \multicolumn{2}{|c|}{$\begin{array}{l}\text { Costs represent a mature grove } \\
(10+\text { years old) including resets }\end{array}$} & $\begin{array}{c}\text { Number } \\
\text { of Applications }\end{array}$ & $\begin{array}{l}\text { Materials Cost } \\
\text { per acre (\$) }\end{array}$ & $\begin{array}{l}\text { Application Cost } \\
\text { per acre (\$) }\end{array}$ & $\begin{array}{c}\text { Total Cost } \\
\text { per acre (\$) }\end{array}$ \\
\hline \multicolumn{6}{|l|}{ Cultural Costs } \\
\hline \multicolumn{6}{|l|}{ Weed Management } \\
\hline & Mowing (Chemical \& mechanical) & 6 & 1.49 & 77.75 & 79.24 \\
\hline Herbi & & 4 & 83.65 & 52.75 & 136.40 \\
\hline \multicolumn{5}{|c|}{ Total Weed Management Costs } & 215.64 \\
\hline \multicolumn{6}{|l|}{ Foliar Sprays } \\
\hline & Insecticides & & 160.53 & & \\
\hline & Fungicides & & 131.95 & & 351.52 \\
\hline & Nutritionals & & 59.04 & & \\
\hline & \multicolumn{5}{|c|}{ Application: } \\
\hline & Ground & 4 & & 116.58 & 116.58 \\
\hline & Aerial & 1 & & 11.61 & 11.61 \\
\hline \multicolumn{5}{|c|}{ Total Foliar Sprays Costs } & 479.71 \\
\hline \multicolumn{6}{|l|}{ Fertilizer } \\
\hline & Ground/Dry Fertilizer & 3 & 215.42 & 25.80 & 241.21 \\
\hline & Fertigation/Liquid Fertilizer & 6 & 143.51 & 3.23 & 146.75 \\
\hline \multicolumn{2}{|l|}{ Total Fertilizer Costs } & & & & 387.96 \\
\hline \multicolumn{6}{|l|}{ Pruning } \\
\hline & Topping \& Hedging & 1 & & 33.28 & 33.28 \\
\hline & Chop/Mow Brush & 1 & & 0.30 & 0.30 \\
\hline Total Pruning Costs & & & & & 33.58 \\
\hline \multicolumn{6}{|l|}{ Irrigation } \\
\hline & Irrigation System ${ }^{1}$ & & & & 76.36 \\
\hline & Fuel for pump & & & & 120.80 \\
\hline \multicolumn{2}{|l|}{ Total Irrigation Costs } & & & & 197.15 \\
\hline \multicolumn{5}{|c|}{ Total Cultural Production Costs without Tree Replacement } & $1,314.04$ \\
\hline \multicolumn{6}{|c|}{ Tree Replacement (6 trees): } \\
\hline & \multicolumn{3}{|c|}{ Tree Removal (Clip-shear; use front-end loader) } & & 32.00 \\
\hline & \multicolumn{3}{|c|}{ Site Preparation and Plant Tree (Includes reset trees) } & & 62.00 \\
\hline & \multicolumn{4}{|c|}{ Supplemental Fertilizer, Sprays, Sprout, etc. (Trees 1-3 years old) } & 99.75 \\
\hline \multicolumn{3}{|c|}{ Total Tree Replacement Costs } & & & 193.75 \\
\hline \multicolumn{5}{|c|}{ Total Cultural Costs with Tree Replacement } & $1,507.79$ \\
\hline
\end{tabular}

Table 2. Total Costs of Production per Acre for Processed Oranges Grown in Southwest Florida, 2020/21.

\begin{tabular}{|c|c|c|}
\hline & & Total Cost per acre $(\$)$ \\
\hline Total Cultura & & $1,507.79$ \\
\hline Other Costs & Interest on Operating (Cultural) Costs & 75.39 \\
\hline & Management Cost & 144.00 \\
\hline & Property Tax/Water Management Assessment & 28.73 \\
\hline & Interest on Average Capital Investment & 126.52 \\
\hline Total Other C & & 374.64 \\
\hline Total Costs & & $1,882.43$ \\
\hline
\end{tabular}


Table 3. Break-Even Price per Box and per Pound Solids for Processed Oranges Grown in Southwest Florida, 2020/21.

\begin{tabular}{|c|c|c|c|c|c|c|c|c|c|}
\hline \multicolumn{10}{|c|}{ A. Early and Mid-Season Oranges } \\
\hline & \multicolumn{9}{|c|}{ Yield (boxes per acre) } \\
\hline & 125 & 150 & 175 & 200 & 225 & 250 & 275 & 300 & 325 \\
\hline & \multicolumn{9}{|c|}{ dollars per acre } \\
\hline $\begin{array}{l}\text { Cost of Production } \\
\text { per acre }\end{array}$ & 1882 & 1882 & 1882 & 1882 & 1882 & 1882 & 1882 & 1882 & 1882 \\
\hline $\begin{array}{l}\text { Pick and Haul per } \\
\text { acre }(\$ 3.22 / \text { box })\end{array}$ & 403 & 483 & 564 & 644 & 725 & 805 & 886 & 966 & 1047 \\
\hline $\begin{array}{l}\text { FDOC assessment } \\
(\$ 0.12 / \text { box })\end{array}$ & 15 & 18 & 21 & 24 & 27 & 30 & 33 & 36 & 39 \\
\hline $\begin{array}{l}\text { Total Delivered- } \\
\text { in Cost per acre }\end{array}$ & 2300 & 2383 & 2467 & 2550 & 2634 & 2717 & 2801 & 2884 & 2968 \\
\hline Break-even Price: & \multicolumn{9}{|c|}{ \$ per box } \\
\hline On-tree & 15.06 & 12.55 & 10.76 & 9.41 & 8.37 & 7.53 & 6.85 & 6.27 & 5.79 \\
\hline Delivered-in & 18.40 & 15.89 & 14.10 & 12.75 & 11.71 & 10.87 & 10.19 & 9.61 & 9.13 \\
\hline Break-even Price:: & \multicolumn{9}{|c|}{ \$ per pound solids } \\
\hline On-tree & 2.92 & 2.44 & 2.09 & 1.83 & 1.62 & 1.46 & 1.33 & 1.22 & 1.12 \\
\hline Delivered-in & 3.57 & 3.09 & 2.74 & 2.48 & 2.27 & 2.11 & 1.98 & 1.87 & 1.77 \\
\hline
\end{tabular}

\section{B. Valencia Oranges}

\begin{tabular}{|c|c|c|c|c|c|c|c|c|c|}
\hline & \multicolumn{9}{|c|}{ Yield (boxes per acre) } \\
\hline & 125 & 150 & 175 & 200 & 225 & 250 & 275 & 300 & 325 \\
\hline & \multicolumn{9}{|c|}{ dollars per acre } \\
\hline $\begin{array}{l}\text { Cost of Production } \\
\text { per acre }\end{array}$ & 1882 & 1882 & 1882 & 1882 & 1882 & 1882 & 1882 & 1882 & 1882 \\
\hline $\begin{array}{l}\text { Pick and Haul per } \\
\text { acre }(\$ 3.33 / \text { box })\end{array}$ & 416 & 500 & 583 & 666 & 749 & 833 & 916 & 999 & 1082 \\
\hline $\begin{array}{l}\text { FDOC assessment } \\
(\$ 0.12 / \text { box })\end{array}$ & 15 & 18 & 21 & 24 & 27 & 30 & 33 & 36 & 39 \\
\hline $\begin{array}{l}\text { Total Delivered-in } \\
\text { Cost per acre }\end{array}$ & 2314 & 2400 & 2486 & 2572 & 2659 & 2745 & 2831 & 2917 & 3004 \\
\hline Break-even Price: & \multicolumn{9}{|c|}{ \$ per box } \\
\hline On-tree & 15.06 & 12.55 & 10.76 & 9.41 & 8.37 & 7.53 & 6.85 & 6.27 & 5.79 \\
\hline Delivered-in & 18.51 & 16.00 & 14.21 & 12.86 & 11.82 & 10.98 & 10.30 & 9.72 & 9.24 \\
\hline Break-even Price: ${ }^{1}$ & \multicolumn{9}{|c|}{ \$ per pound solids } \\
\hline On-tree & 2.66 & 2.22 & 1.90 & 1.66 & 1.48 & 1.33 & 1.21 & 1.11 & 1.02 \\
\hline Delivered-in & 3.27 & 2.83 & 2.51 & 2.27 & 2.09 & 1.94 & 1.82 & 1.72 & 1.63 \\
\hline
\end{tabular}

